\title{
Comparison of wheat spindle streak mosaic virus (WSSMV) and barley yellow mosaic virus (BaYMV): 2 closely related bymoviruses
}

\author{
A Sohn ${ }^{1 *}$, P Schenk ${ }^{1}$, J Hamacher ${ }^{3}$, PA Signoret ${ }^{2}$, HH Steinbiß ${ }^{1}$ \\ 1 Max-Planck-Institut für Züchtungsforschung, Carl-von-Linné-Weg, 10, D-50829 Cologne, Germany; \\ 2 UFR de biologie et pathologie végétales, ENSA, 2, place Viala, F-34060 Montpellier cedex, France; \\ 3 Institut für Pflanzenkrankheiten, Nußallee 9, D-53115 Bonn, Germany
}

(Received 20 May 1995; accepted 4 July 1995)

\begin{abstract}
Summary - In order to better understand the evolutionary development that leads to different host ranges, we made a comparison of the closely related barley yellow mosaic bymovirus (BaYMV) and wheat spindle streak mosaic bymovirus (WSSMV). Using different methods both viruses were found to be closely related. Leaves of BaYMV-infected winter barley and WSSMV-infected wheat typically showed similar symptoms. Electron microscopy studies revealed that both viruses lead to formation of 2 types of cytoplasmic inclusions bodies ( $\mathrm{Cl}$, 'pinwheel' structures; crystal-like respectively membranous) in infected cells that showed structural differences. This close relationship is also reflected by the high degree of amino acid sequence homology (74\% in CP-, $83 \%$ in Nlb-, $68 \%$ in Nla-region). In spite of the remarkably high similarities both viruses have separate hosts. We demonstrated that, independently of the host range, a reliable distinction between WSSMV and BaYMV is possible using Northern blot hybridisation, reverse transcriptasepolymerase chain reaction (RT-PCR) and Western blot analysis. Antisera raised against BaYMV proteins also detected WSSMV proteins in Western blot analyses. Even though corresponding proteins of both viruses were usually similar in size, the BaYMV-Cl antiserum cross-reacted with an additional protein about $8 \mathrm{kDa}$ larger in wheat extracts and the BaYMV $28 \mathrm{kDa}$ antiserum detected a protein of about $30 \mathrm{kDa}$ in wheat extracts.
\end{abstract}

bymovirus / barley yellow mosaic virus / wheat spindle streak mosaic virus / Polymyxa graminis / host range

Résumé - Comparaison du virus de la mosaïque striée du blé (WSSMV) et du virus de la mosaïque jaune de l'orge (BaYMV) : 2 bymovirus très proches. Dans le but de mieux comprendre l'évolution qui mène à différentes gammes d'hôtes de virus transmis par des champignons, nous avons comparé le virus de la mosaïque jaune de l'orge (BaYMV) et le virus de la mosaïque striée du blé (WSSMV). En utilisant différentes méthodes, nous avons remarqué que les 2 virus étaient très proches. Les feuilles de l'orge d'hiver infecté par le BaYMV et du blé infecté par le WSSMV ont révélé des symptômes similaires. Des études au microscope électronique ont montré que les 2 virus entraînaient la formation d'inclusions cytoplasmiques cylindriques $(\mathrm{Cl}$; structure "pinwheel") dans les cellules infectées et ont souligné quelques différences structurelles. Ce lien de parenté est également révélé par la forte homologie des séquences d'acides aminés et de cADN (74\% en CP, $83 \%$ en NIb et $68 \%$ en Nla). Jusqu'à présent, le BaYMV et le WSSMV avaient été distingués sur le seul critère des plantes hôtes. Nous avons montré que, indépendamment de la gamme d'hôtes, des distinctions reproductibles entre WSSMV et BaYMV sont possibles en Northern RT-PCR (transcription reverse associée à la réaction de polymérase en chaine) et Western blot. Bien que les protéines correspondantes des virus aient généralement une taille similaire, l'antisérum dirigé contre la protéine Cl du BaYMV a réagi chez le blé avec

\footnotetext{
* Correspondence and reprints
} 
une protéine supplémentaire d'une taille de $8 \mathrm{kDa}$ supérieure à celle de la protéine homologue, tandis que l'antisérum dirigé contre la protéine "28 kDa" du BaYMV reconnaît chez le blé une protéine de $30 \mathrm{kDa}$.

\section{bymovirus / virus de la mosaïque jaune de l'orge / virus de la mosaïque striée du blé / Polymyxa graminis /} hôte

Yellow mosaic diseases of barley and wheat caused by Polymyxa graminis transmitted RNA viruses lead to considerable damage and yield losses in many European countries (Signoret, 1977; Rubies-Antonell et al, 1987). Bymoviruses, such as barley yellow mosaic virus (BaYMV) and barley mild mosaic virus (BaMMV) infecting winter barley and wheat spindle streak mosaic virus (WSSMV) and wheat soilborne mosaic virus (WSBMV) infecting wheat, give rise to heavy infections (Huth, 1981; Miller et al, 1992). In this paper we present common features and differences of BaYMV and WSSMV by using several molecular biology and electron microscopy techniques.

Both viruses contain a bipartite positive-sense, single-stranded RNA genome. The slightly flexous, rod-shaped particles are of length about 350 and $650 \mathrm{~nm}$ (Slykhuis and Polak, 1971; Usugi and Saito, 1979; Huth et al, 1984). Particles are often found in aggregation. In the cell they appear as clusters and are rarely found as single virus particles in infected cells.

Electron microscopy studies of infected cells showed cytoplasmatic cylindrical inclusion bodies (Cl, 'pinwheel' structures) which are typical for viruses of the family Potyviridae (Hooper and Wiese, 1972; Huth et al, 1984). In comparison to BaYMV the pinwheel inclusions of WSSMV infected cells consisted of more curved 'arms' and were accompanied more obviously by membranous invaginations between the 'arms' which appeared in cross-sections as vesicle-like structures (Hooper and Wiese, 1972). The other predominant feature in BaYMV-infected cells were crystal-like cytoplasmic inclusion bodies. Immunogold labeling studies with antisera raised against BaYMV-RNA2 encoded proteins $(28 \mathrm{kDa}$, $70 \mathrm{kDa}$ ) revealed that the proteins are part of this structure (Schenk et al, 1993). The same antisera also detected cytoplasmatic inclusions in WSSMV infected cells but of a more membranous type (fig 1).

Taken together the leaf symptoms and cellular alterations were similar except that the morphology of the cytoplasmatic inclusion bodies was different. These structures contained the same viral proteins as could be shown in immunogold-

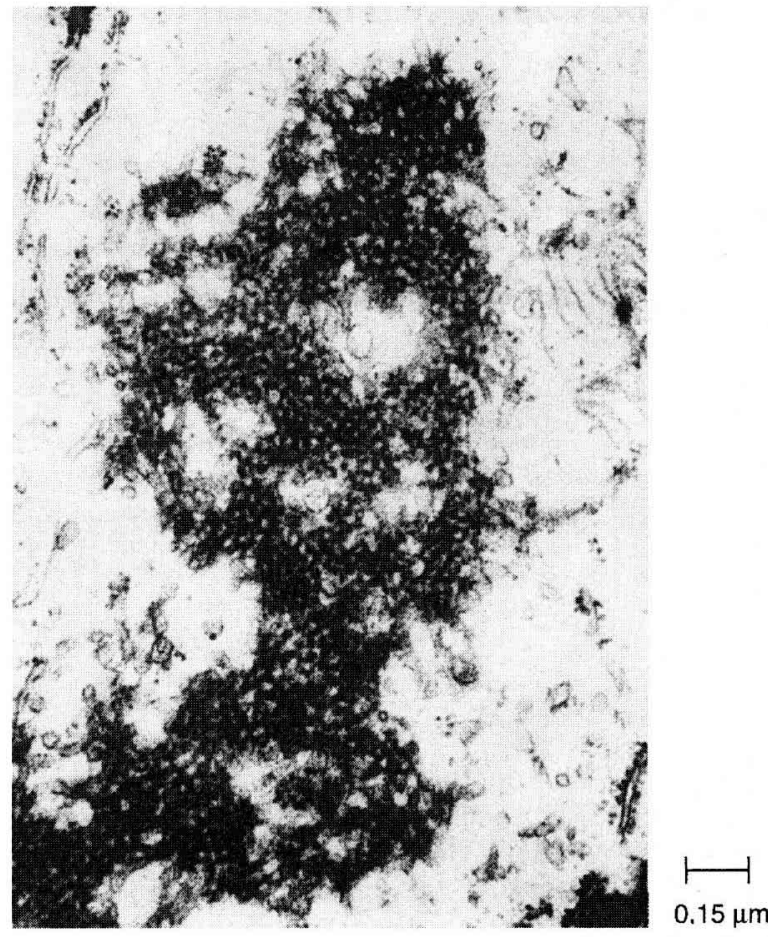

Fig 1. Electron microscopy of cytoplasmic inclusion bodies in cells of WSSMV-infected wheat leaves.

labeling studies. It is unknown whether the differences of the corresponding viral proteins are responsible for the differences in morphology or whether plant proteins play a role.

The high degree of relationship is also displayed by comparison of the accessible viral sequences (Sohn et al, 1994). Each viral RNA codes for an autoproteolytically processed polyprotein as is known from the analysis of the complete sequenced BaYMV genome (Kashiwasaki et al, 1990; Davidson et al, 1991; Peerenboom et al, 1992; Schenk et al, 1993) and as can be concluded from the known RNA1 sequence of WSSMV. Sequence comparison of the capsid protein $(\mathrm{CP})$ region, which was often successfully used as a taxonomic parameter, revealed a very high overall $\mathrm{CP}$ identity $(74 \%)$ and a homology in the $C P$ core regions of WSSMV and BaYMV of $81 \%$. This is in the reported range of $75-88 \%$ for very closely related viruses, which are regarded as distinct viruses (Sohn et al, 1994). 
In spite of these remarkably high similarities both viruses have separate hosts (Slykhius, 1970; Jackson et al, 1976). Inoculation of barley plants with WSSMV has always been unsuccessful and, to our knowledge, BaYMV has never been detected in barley planted on a WSSMVinfected field. Independent of testing the host range, it is possible to distinguish between the 2 viruses using molecular biology techniques such as Northern blot hybridization, reverse transcriptase-polymerase chain reaction (RT-PCR) and Western blot analysis.

Poly(A) RNA from $200 \mathrm{mg}$ infected leaves were isolated using oligo-d(T)25 Dynabeads (Dynal). Useful cDNA probes could be found which hybridised with RNA1 or RNA2 of both viruses (fig 2). Cross-hybridisation of RNA1 and RNA2 has never been found. Interestingly RNA2 detection showed not only the expected signal at approximately $3.5 \mathrm{~kb}$ but moreover a smaller RNA of approximately $1.8 \mathrm{~kb}$. This RNA could be due to the isolation procedure resulting in a damaged, shorter RNA2 fragment, or it may be possible that this is a deletion containing a form of the RNA2 as was reported for BaMMV RNA2 (Dessens et al, 1995; Jacobi et al, 1995).

Using the same Northern blot conditions (a cDNA fragment corresponding to the 3 ' terminal $\mathrm{NIb}$ region and the $5^{\prime}$ terminal CP region of WSSMV RNA1 (62\% sequence homology to BaYMV) as a probe for hybridisation only the RNA1 of WSSMV-infected plants gave a signal.

The isolated poly(A) RNA from infected leaves was also tested with RT-PCR using WSSMV-

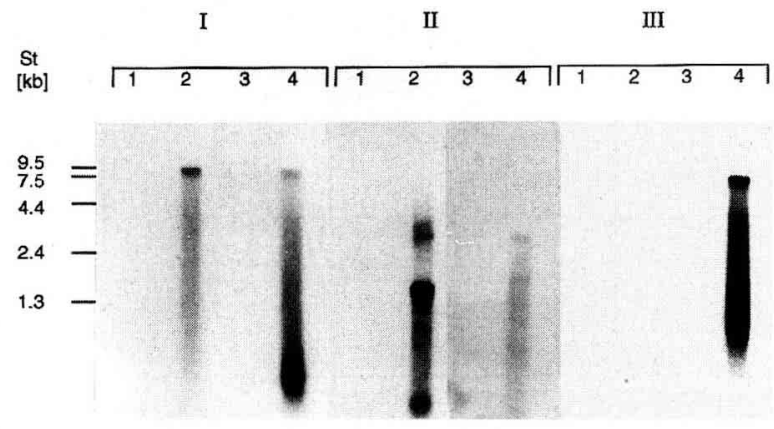

Fig 2. Northern blot analysis of poly(A) RNA isolated from BaYMV infected (2) or uninfected healthy barley leaves (1) and from WSSMV infected (4) or uninfected wheat leaves (3). The blotted filter was prehybridised with a formamide containing solution at $42^{\circ} \mathrm{C}$ for $4 \mathrm{~h}$, hybridised overnight and was washed with $6 \times 4 \times$ and $2 \times$ SSC, $1 \%$ SDS at $45^{\circ} \mathrm{C}$. The following cDNA fragments were used for as labeled probes for hybridization: I. A $4.4 \mathrm{~kb}$ Sall fragment corresponding to the $3^{\prime}$ terminal part of the RNAt of BaYMV; II. A $2.8 \mathrm{~kb}$ Nrul and Nsul cut cDNA fragment corresponding to the 3 ' terminal part of the RNA2 of BaYMV; III. A $330 \mathrm{bp}$ Hincll cDNA fragment corresponding to the $3^{\prime}$ terminal NIb region and the $5^{\prime}$ terminal CP region of the RNA1 of WSSMV. specific primers. Using poly(A) RNA from WSSMV-infected leaves for RT-PCR, a $960 \mathrm{bp}$ fragment could be detected after electrophoretic separation on agarose gel. Cutting the PCR fragment that corresponds to the part of the $C P$ region with restriction enzymes (Pvull, Hind III) resulted in a fragment length pattern which was expected from the WSSMV CDNA sequence (data not shown). This ensured that the expected WSSMV fragment was amplified. Starting with BaYMV-infected leaf material or corresponding BaYMV cDNA, no fragment was amplified by RTPCR under these conditions (fig 3 ) because the homology of the primers was not sufficient enough.

The described primers turned out to be useful to distinguish between WSSMV and BaYMV. They may be also useful for investigations of the Japanese wheat yellow mosaic virus (WYMV), which is thought to be a strain of WSSMV or vice versa. It would be interesting to see if a similar fragment could be amplified. Furthermore, the restriction sites in the primers (a: BamHI, b: Ndel) allowed easy cloning of an amplified fragment in a suitable vector for sequencing.

Serological studies have shown that all polyclonal antisera raised against proteins of BaYMV detected similar proteins of WSSMVinfected cells and vice versa (Usugi and Saito,

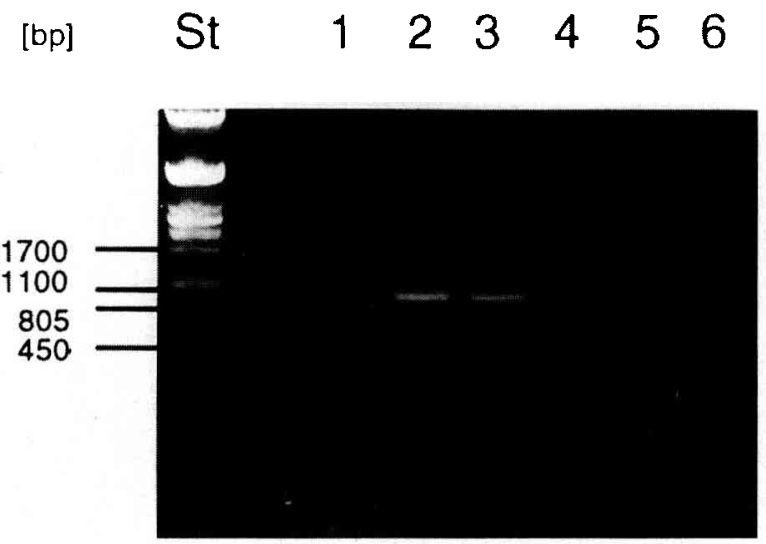

Fig 3. Agarose gel electrophoresis of RT-PCR products. Reverse transcribed poly(A) RNA isolated from healthy (1), WSSMV infected wheat leaves $(2,3)$, BaYMV infected barley (4) and as controls cDNA corresponding to BaYMV RNA1 (5) and to WSSMV RNA1 (6) were used for PCR amplification with primer a (5'CCA CAC GGG ATC CGC) complementary to the $3^{\prime}$ and $5^{\prime}$ part of the WSSMV CP region. A quarter of the isolated RNA and 120 pmol primer a was used for the first strand synthesis with $1 \mu \mathrm{l}$ 'superscript' reverse transcriptase (BRL), $10 \mathrm{mM}$ NTPs, buffer, $1 \mu \mathrm{l}$ RNasin, $0.01 \mathrm{M}$ DTT for $1 \mathrm{~h}$ at $37^{\circ} \mathrm{C} ; 1 / 20$ of this reaction was then used for PCR with 50 pmol of each primer (a,b), $2.5 \mathrm{mM}$ dNTPs, buffer and 2.5 units Taq-polymerase (Amersham). The following conditions were suitable: 30 cycles $2 \mathrm{~min}$ at $92^{\circ} \mathrm{C}$ and $2 \mathrm{~min}$ at $72^{\circ} \mathrm{C}$. Probes containing sequences of WSSMV have lead to the amplification of the expected $960 \mathrm{bp}$ fragment. 

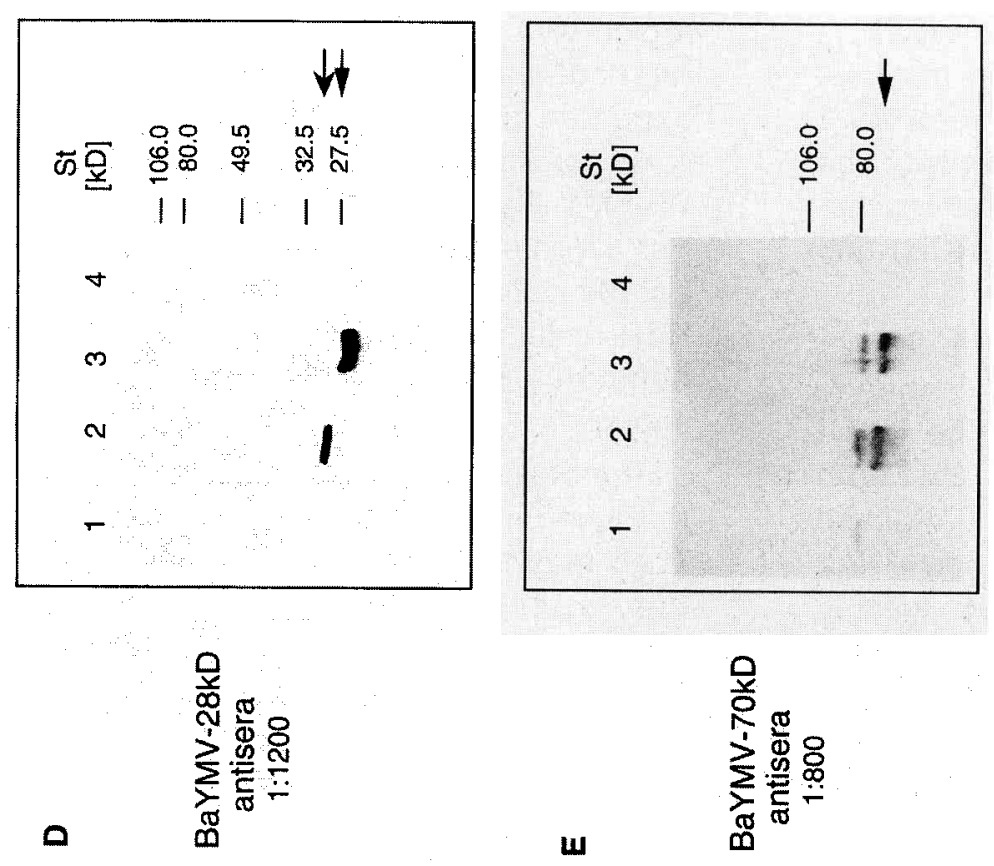
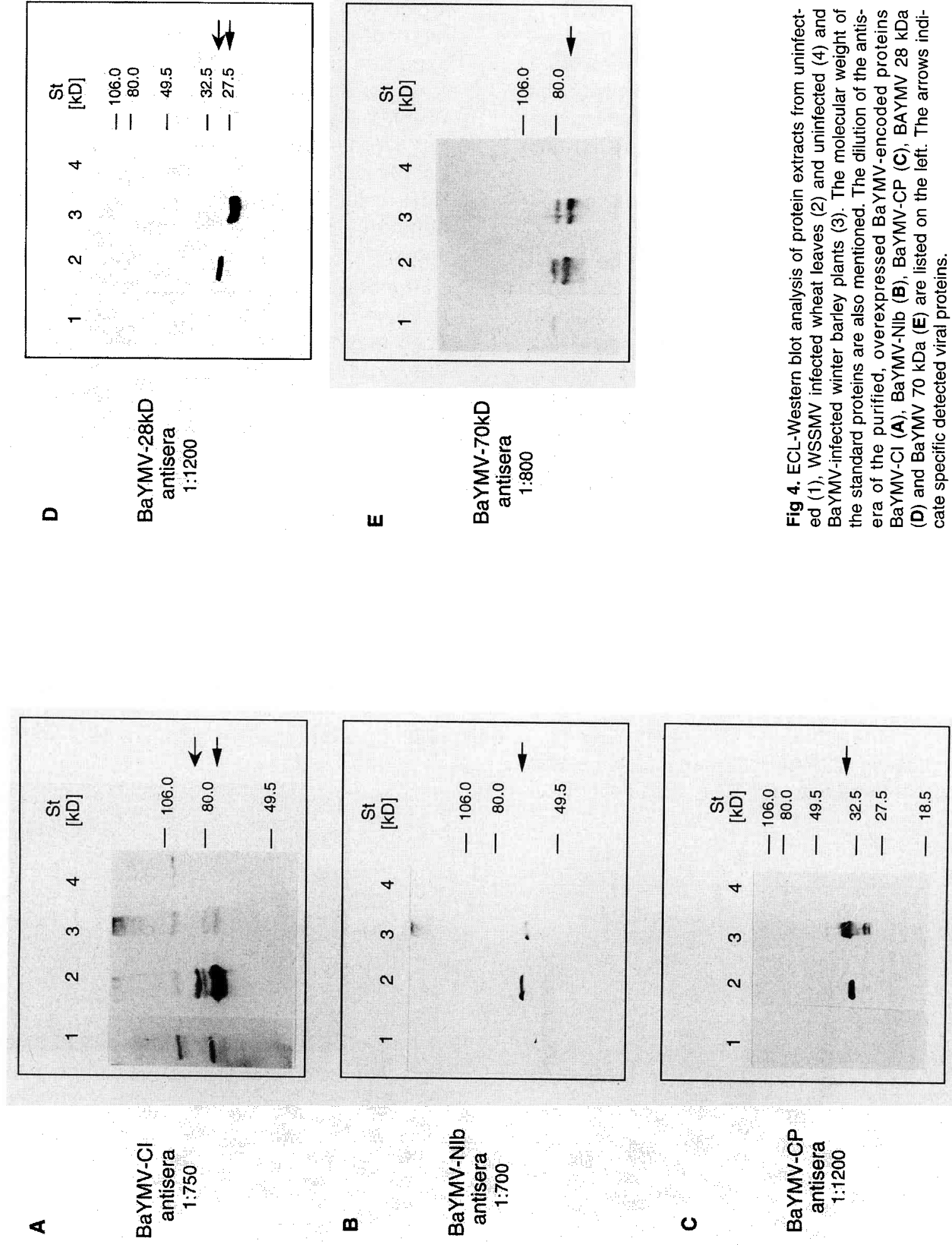
1976; Langenberg, 1986; Chen and Adams, 1991). A distinction by using these antisera for ELISA is not possible. In this study we have tested antisera in Western blot analyses which were raised against purified BaYMV proteins that were over-produced in Escherichia coli, such as the RNA1 encoded $\mathrm{Cl}, \mathrm{NIb}, \mathrm{CP}$ and both the RNA2 encoded proteins $(28 \mathrm{kDa}, 70$ $\mathrm{kDa}$ ). Proteins of the same molecular weight were detected with these antisera in BaYMVand WSSMV-infected leaf extracts (fig 4) with the following 2 exceptions. The BaYMV-Cl antisera detected in WSSMV extracts an additional protein which is about $8 \mathrm{kDa}$ higher. A possible explanation for this might be an inefficient processing of a putative additional Nla processing site at the N-terminal site of the $\mathrm{Cl}$ region, which is known for potyviruses (Garcia et al, 1992). However, the sequence data of WSSMV for this region are still missing.

The other difference could be detected with BaYMV $28 \mathrm{kDa}$ antisera which reacted in Western blot analyses of WSSMV-infected leaf extracts with a protein of $30 \mathrm{kDa}$ which is slightly but significantly higher than the BaYMV RNA2 encoded $28 \mathrm{kDa}$ protein. Further investigations of the RNA2 of WSSMV will be made in the future, especially with emphasis on further differences to BaYMV. To understand the virus-plant interactions that lead to different host ranges or to preference of races of $P$ graminis to one of these viruses would be very helpful for the development of a resistance strategy.

\section{REFERENCES}

Chen J, Adams MJ (1991) Serological relationship between 5 fungally transmitted cereal viruses and other elongated viruses. Plant Pathol 40, 226-231

Davidson AD, Pröls M, Schell J, Steinbiß HH (1991) The nucleotide sequence of RNA 2 of barley yellow mosaic virus. J Gen Virol 72, 989-993

Dessens JT, Nguyen M, Meyer M (1995) Primary structure and sequence analysis of RNA2 of a mechanically transmitted barley mild mosaic virus isolate: an evolutionary relationship between bymoand furoviruses. Arch Virol 140, 325-333

Garcia JA, Matin MT, Cervera MT, Riechmann JL (1992) Proteolytic processing of the plum pox polyprotein by Nla proteinase at a novel cleavage site. Virology $188,697-703$

Hooper GR, Wiese MV (1972) Cytoplasmic inclusion in wheat affected by wheat spindle streak mosaic virus. Virology 47, 664-672

Huth W (1981) Das Gelbmosaikvirus der Gerste. BASF-Mitteil, Landbau BASF Agric Bulletin 4
Huth W, Lesemann DE, Paul HL (1984) Barley yellow mosaic virus: purification, electron microscopy, serology, and other properties of 2 types of the virus. Phytopath Z 111, 37-54

Jackson AO, Bracker CE, Shaner G (1976) Mechanical transmission, varietal reactions and electron microscopy of a disease in Indiana with properties of wheat spindle streak mosaic virus. Plant Dis Rep 60, 202-206

Jacobi V, Peerenboom E, Schenk PM, Antoniw JF, Steinbiß HH, Adams MJ (1995) Cloning and sequence analysis of RNA2 of a mechanically transmitted UK isolate of barley mild mosaic bymovirus (BaMMV). Virus Res 37, 99-111

Kashiwasaki S, Minobe Y, Omura T, Hibino H (1990) Nucleotide sequence of barley yellow mosaic virus RNA 1: a close evolutionary relationship with potyviruses. J Gen Virol 71, 2718-2790

Kashiwasaki S, Minobe $Y$, Hibino H (1991) Nucleotide sequence of barley yellow mosaic virus RNA2. J Gen Virol 72, 995-999

Langenberg (1986) Virus protein association with cylindrical inclusions of 2 viruses that infect wheat. $J$ Gen Virol 67, 1161-1168

Miller NR, Bergstrom GC, Sorrels ME (1992) Effect of wheat spindle streak mosaic virus on winter wheat in New York. Phytopathology 82, 852-857

Peerenboom E, Pröls M, Schell J, Steinbiß HH, Davidson A (1992) The complete nucleotide sequence of RNA1 of a German isolate of barley yellow mosaic virus and its comparison with a Japanese isolate. J Gen Virol 73, 1303-1308

Rubies-Autonell C, Vallega $V$ (1987) Observation of a mixed soil-borne wheat mosaic virus and wheat spindle streak mosaic virus infection in durum wheat (Triticum durum). J Phythol 119, 111-121

Schenk PM, Steinbiß HH, Müller B, Schmitz K (1993) Association of 2 barley yellow mosaic virus (RNA2) encoded proteins with cytoplasmic inclusion bodies revealed by immunogold localization. Protoplasma 173, 113-122

Signoret PA, Alliot B, Poinso B (1977) Présence en France du wheat spindle streak mosaic virus. Ann Phythol 9, 377-379

Slykhuis JT (1970) Factors determining the development of wheat spindle streak mosaic virus caused by a soil-borne virus in Ontario. Phytopathology 60, 319-331

Slykhuis JT, Polák Z (1971) Factors affecting manual transmission, purification, and particle lengths of wheat spindle streak mosaic virus. Phytopathology 61, 569-574

Sohn A, Schenk P, Signoret PA, Schmitz G, Schell J, Steinbiß HH (1994) Sequence analysis of the 3 ' terminal half of RNA1 of wheat spindle streak mosaic virus. Arch Virol 135, 279-292

Usugi T, Saito $Y$ (1979) Relationship between wheat yellow mosaic virus and wheat spindle streak mosaic virus. Ann Phytopath Soc Jpn 45, 397-400 